\title{
Mathematical and Scriptural aspect of Mekhala in the Construction of Yagya Kund
}

\author{
Ekta Chandel $^{1}$
}

${ }^{1}$ Visiting scientist, Yagyavalkya Center for Yagya Research, Dev Sanskriti University, Haridwar, India *Corresponding. Email: ektachandel8@gmail.com

https://doi.org/10.36018/ijyr.v4i1.67

\begin{abstract}
Yagya kund has five parts - Khat, Nabhi, Kant, Mekhla and Yoni. The construction of Yagya kund shall be done with proper consideration of all of its parts. The final shape and appearance of the Yagya kund came after the construction of Mekhala. Mekhala is an object which surrounds another object by keeping that object in the middle. For Yagya kund, Mekhala surrounds the fire pit which provides the shape to the Yagya kund. The present paper attempts to describe the mathematical and scriptural aspects of Mekhala i.e. description of Mekhala and Khat, shape, number of Mekhala, and significance. The number of Mekhala varies by the size of Yagya Kund, the number of offerings, and the purpose of Yagya. The study also described the dimension of all types the Mekhala construction for 1 hast Kund indicating the important role of Mekhala in the Yagya Kund construction.
\end{abstract}

Keywords. Mekhala, Yagya Kund construction, Number of Mekhala, Dimension of Mekhala

\section{Introduction}

Yagya is one of the main foundations of Indian Vedic culture. Yagya is not just a mere ritual for local welfare but it has wider applications. Veda describes that Yagya brings harmony and stability in the ecological cycles (1). In fact, the purview of Yagya includes the whole universe and all of its activity and functions. The proper flow of all the activities and functions of the universe is only possible because of Yagya (harmony \& ecological balances), and hence, Atharveda states that अयं यज्ञो विश्वस्य भुवनस्य नाभिः । (Ayam Yagyo vishwasya buvanasya Nabhihi) - it means - Yagya is the nucleus of the universe (2). Besides universal philosophy, the practical portion of the ritual containing Tools, Kund, Mandap, etc has also been very well defined in terms of purpose, construction and performance of the ritual. According to the 'YagyaMadhusoodan: स्मार्तकुण्ड समीक्षा अध्यायः (Smart-KundSamiksha-Adhyayah)' chapter 'atha-khatah' (अथ खातः), Yagya kund has 5 parts. It states - अतः परमेषां पंचाड्गानि खात, नाभि, कण्ठ, मेखला, योनिरूपाणि यथाकर्म प्रदर्श्यन्ते। (Atah parmesham panchaangani khat, nabhi, kant, Mekhala yonirupani yathakarm pradarshyante). It means the Yagya Kund has five parts: Khat, Nabhi, Kant, Mekhla and Yoni (3, page 46). Among them, the present manuscript focuses only on dimensions of Mekhala of Yagya Kund covering mathematical and scriptural aspects.

The word 'Mekhala' is an object surrounding the other object by keeping that object in its middle (4). The construction of Yagya kund shall be done with 
proper consideration of all of its parts. The final shape and appearance of the Yagya kund comes after the construction of Mekhala. In scripture, Rishis recommend worshipping Yagya kund (shape and appearance) as the physical body of Deity (5) (6, shloka 31). The present paper discussed the shape, construction, numbers and significance of Mekhala.

\section{Shape of Mekhla}

According to Sharda Tilak book Volume- I, 'तृतीय पटल’ (Tritiya Patal), ‘मेखला लक्षणं' (Mekhala Lakshan) Shloka 67, 'कुण्डानां यादृशं रूपं मेखलानाइच तादृशं ।' (Kundanam yadrasham roopam Mekhalanagych tadrasham). It means - The shape of Mekhala is the same as the shape of yagya kund (7). It implies that if the shape of yagya kund is square then Mekhala will also be square in shape around the Yagya kund; if the shape of yagya kund is octagonal then Mekhala will be octagonal in shape, and so on. This scripture affirmation has also been given in YagyaMadhusoodan (3, page 46).

\section{Types of Khat (depth of Kund) with reference to Mekhala}

Khat is a depth of Kund. There are two kinds of considerations for deciding the depth (Volume) of Yagya Kund i.e. 1) Kund Volume containing Mekhala with Khat, 2) Kund volume containing only Khat without Mekhala (8, Page 72).
1) Kund Volume containing Mekhala with Khat - In this type of Yagya kund the total volume of yagya kund includes depth of khat and height of Mekhala. For example, if the kund is 1 hast (24 angul), then the total volume of Kund will consist of the depth of khat (15 angul) and the height of Mekhala (9 angul).

Total volume (depth) of Yagya kund = depth of khat + height of Mekhala.

2) Kund volume containing only Khat - In this type of Yagya kund the total volume of Yagya kund includes only depth of Khat and excludes height of the Mekhala. For example, if the Kund is 1 hast (24 Angul), then, in that case, the total volume of Kund (24 Angul) will consist of the depth of Khat (24 Angul) only and will exclude the height of Mekhala (9 angul).

Total height (depth) of Yagya kund = depth of khat (height of Mekhala is additional and not considered in Yagya Kund volume)

Khat with Mekhala is constructed when Havi (Hawan Samagri \& other items to be offered in Yagya Kund) are Sukshma (coarse and not bulky), while Khat with Mekhala is constructed when Havi is bulky in shape i.e. Indian Bael-fruit (Aegle marmelos), Charu, etc (8, page 72 ).

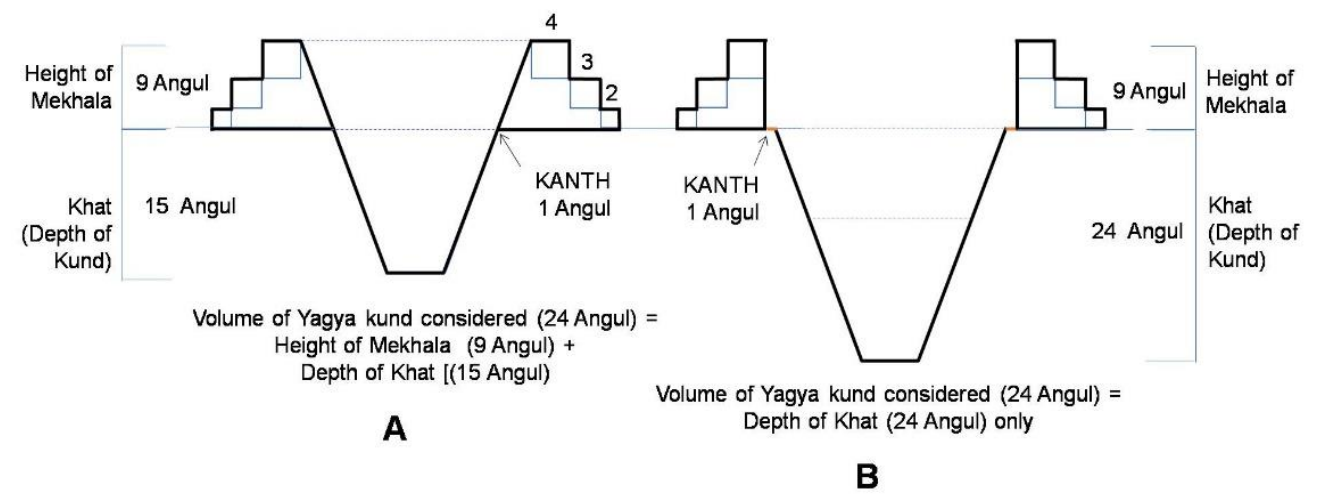

Figure 1. Types of Khat (depth of Kund) with reference to Mekhala. A) Kund Volume containing Mekhala with Khat, B) Kund volume containing only Khat. 


\section{Consideration of Kanth}

Scriptures describe how to create a Kanth in the Yagya Kund. According to Pingalamat given in Kundratnavali Bhumika (Preface), खातादेकांड्गुलम् त्यक्त्वा मेखलानां स्थितिर्भवेत् | - (khatadekangulam tyaktva Mekhalanam isthitirbhavet). It means Mekhala should be constructed after leaving 1 Angul of space (spacing horizontally on Bhumi-surface) after digging Khat during Kund construction (9; Page 12).

According to Sharda Tilak Tamtram, मेखलानां भवेदन्तः परितो नेमिरड्गुलात। एकहस्तस्य कुण्डस्य वर्द्धयेत् तत् क्रमात् सुधीः। दशहस्तान्तमन्येषां अर्द्धांड्गुलवशात् पृथक् ॥ (Mekhlanam bhavedantah parito menirangulat, ekhastsya kundasya vardhdyet tat kramat sudhih. Dashhastantmanyesham ardhdangulvashat prathak). It means - if Kund is of 1 hast, then inside Mekhala on all the periphery, create Kanth of 1 Angul dimension. The Kanth size shall also increase as Kund capacity i.e. increase $1 / 2$ angul per capacity of Kund increase by each Hast (7, 'नेमी लक्षणं' (Nemi Lakshan), Shloka 70).

Also according to Yagya-Madhusoodan, खातादेकाड्ग्गुलम् त्यक्त्वा मेखलानां विधिर्भवेत्। एकाड्ग्गुलः स कण्ठः स्यांमेखला खातमध्यग:॥ इत्युक्तेः। वृध्दौ तु द्विहस्ते द्वियंड्गुलम, त्रिहस्ते त्यंड्गुलम, दशहस्ते दशाड्गुलमि स्येवं नेयम् ॥ कुण्डपज्चाड्गनिम्म्माणेड्ग्गुमानस्य पारिभाषिकत्वात् ॥ (Khatadekangulam tyaktva mekhlanam vidhirbhavet, ekangulah sa kantah swanmekhlam khatmadhyamah. Ityukteh vradhdau tu duhaste dviyangulam, trihaste triangulam, dashate dasaangulami tyevam neyam. Kund panchangnirmaneangulmaansya paribhatiktvaat). It implies that make 2 angul Kanth for 2 hast, 3 angul kanth for 3 hast kund, 10 angul kanth for 10 hast kund, and likewise (3, chapter अथ कंठ: (atha kanthah)).

As above described, Sharada Tilak Tamtram recommends an increment of $1 / 2$ angul of Kanth per increment for every 1 hast of Kund, while YagyaMadhusoodan book recommends an increment of 1 angul of Kanth per increment for every 1 hast of Kund.

\section{Construction of Mekhala}

The size-dimension of Mekhala depends on the dimensions of Kund (1 hast, 2 hast, etc) and the number of Mekhala aimed for performing Yagya. The following description implies the consideration of the size variation of Mekhala to be considered for constructing Yagya kund with different numbers of Mekhala.

\section{For Yagya Kund with One Mekhala}

According to Mandapkund Siddhi, as per Pingalamat 'एका षडड्गुलोत्सेधा विस्तारा मेखला मता । (eka shadangulotsedha vistara mekhla mata), it means the dimension for 1 Mekhala in Yagya Kund is 6 angul (outer height and width) (8, Page 86 , chapter $3)$. The same description for only 1 Mekhala in Yagya Kund has been given in YagyaMadhusoodan (3). It implies that for 1 hast of the Kund with only 1 Mekhala, the size (height and width) of Mekhala is $1 / 4$ of the hast (3). For example, 1 hast (24 angul) Kund, the size (outer height and width) of Mekhala will be 24/4 = 6 Angul. In 1 hast Kund with only one Mekhala, the outer height and width of Mekhala will be 6 angul only. This formula (i.e. $1 / 4$ of the no. of the hast) of Mekhala calculation for 'Kund with only 1 Mekhala' is also applicable for 2 hast, 3 hast, 4 hast, etc. accordingly (8).

Sharda Tilak Tantram mentioned the same formula as described above and stated that it has been also mentioned by Indian scripture Siddhant Shekhar, Somshambhu, Mahakapilpanchratre and Pratham (7, page 208).

Other opinions in addition to above stated opinions for the dimension of Mekhala for 1 Mekhala Yagya Kund also mentioned in the scripture. Yagya- 
Madhusoodan mentioned that as per the Vidhanparijat for 1 Mekhala kund the height of Mekhala is of 4 angul and width is of 6 angul. 'एका पक्षे तस्या षडड्गुलो विस्तार श्रतुर्ग्गुलस्तूच्छाायो विधीयते।' (Eka pakshe tasya shad angulo vistar shchturangulostuchchhrayo vidhiyate), it means the height of Mekhala shall be 4 angul and its width shall be 6 angul (3) (8, page 49).

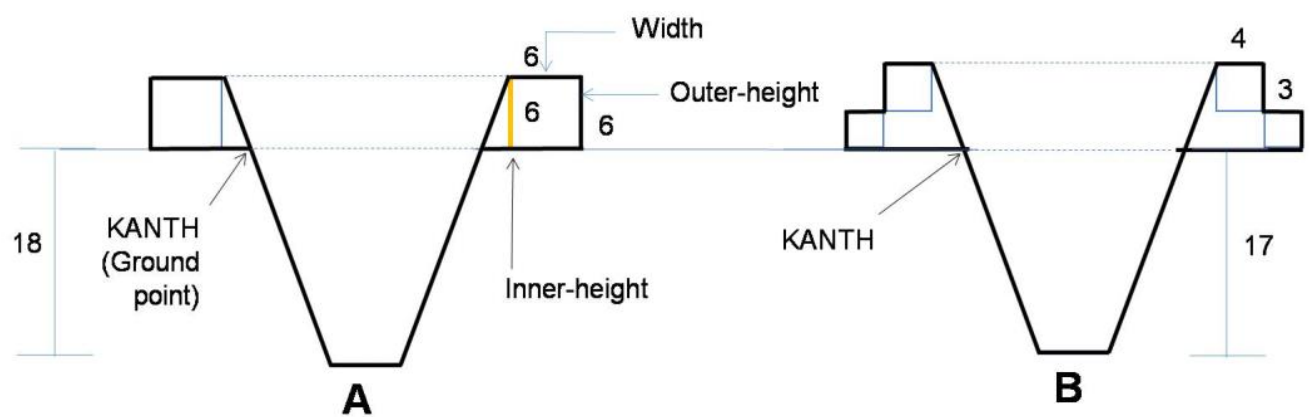

Figure 2. Dimensions of Mekhala in Yayga kund with A) one Mekhala, and B) Two Mekhala.

\section{For Yagya Kund with only Two Mekhala}

According to ‘तंत्रान्त्रोकक्त' (Trantantrokte) in Sharda Tilak Tantram, for construction of 2 Mekhala yagya kund it has been mentioned that 'षष्टाम् शेनाष्टमांशेन मेखलाद्वितयं मतम् ।' (Shashtam shenashtmanshen mekhladvitayam matam) (7). It means for 2 Mekhala construction the first Mekhala dimension (outer height and width) will be $1 / 6$ of the hast of the Kund and the outer height and width of the second Mekhala will be $1 / 8$ of the hast of the Kund. For example for 1 hast kund (24 angul), the dimension (outer height and width) of the first Mekhala is 4 angul ( $1 / 6$ of 24$)$ and the dimension (outer height and width) of the second Mekhala is 3 angul ( $1 / 8$ of 24) (7, page 208). The same reference of “तंत्रान्त्रोकक्त” (Trantantrokte) has also been mentioned in YagyaMadhusoodan (3, page 50).

The other opinion given in Kund-Pradeep book for 2 Mekhala Kund is also mentioned in YagyaMadhusoodan (3). It states, 'द्वेमेखलापक्षे तू ते द्वे मेखले पज्चाड्ग्रुल चतुरड्गुले कार्य्ये ।' (dveMekhalapakshe tu te mekhale panchangulachaturangule karyye). It implies that the yagya kund with 2 Mekhala have first Mekhala of 5 angul dimension (outer height and width) and second Mekhala is of 4 angul dimension (outer height and width) (3).

In summary, for 2 Mekhala Yagya Kund, तंत्रान्त्रोकक्त' (Trantantrokte) opinion recommends 1st Mekhala of 4 angul and 2nd Mekhala of 3 angul, while opinion of Kund-Pradeep book recommends 1st Mekhala of 5 angul and 2nd Mekhala of 4 angul. However, the former 'तंत्रान्त्रोकक्त' (Trantantrokte) opinion is also reflected in 'कपिलपज्चरात्रा' (Kapilpanchratra) opinion for 3 Mekhala Kund, which concludes that the dimensions of the two Mekhala yagya kund are similar to the first two Mekhala of 3 Mekhala yagya kund (3, page 50). Thus, a diagram of two Mekhala as per the opinion of ‘तंत्रान्त्रोकक्त' (Trantantrokte) is given in Figure 2.

\section{For Yagya Kund with only Three Mekhala}

The description for three Mekhala Kund is widely available in the scriptures. The dimension of Mekhala for Yagya kund with three Mekhala is given in figure 3. In addition, the present study described 3 different opinions for Mekhala construction for Yagya kund with 3 Mekhala, which are depicted in Figure 4 and described as following. 


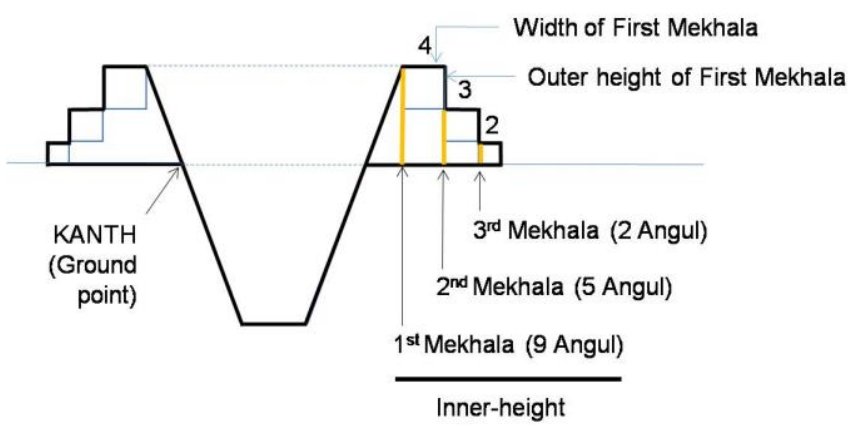

Figure 3. Dimensions of Mekhala in Yayga kund with three Mekhala. All numbers in the figure are in unit 'angul'.

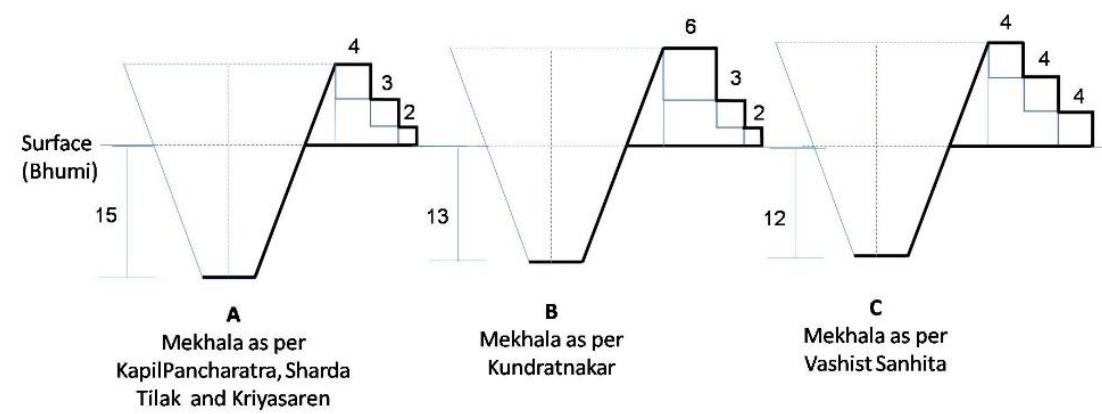

Figure 4. Three different opinions for Mekhala construction for Yagya kund with 3 Mekhala. A) Mekhala calculation as per KapilPancharatra, Sharda Tilak and Kriyasaren, B) Mekhala calculation as per Kundratnakar, C) Mekhala calculation as per Vashist Sanhita. All numbers in the figure are in unit 'angul'.

1) Three Mekhala calculations as per KapilPancharatra, Sharda Tilak and Kriyasaren As per the 'कपिलपज्चरात्रा' (Kapilpanchratra) formula for calculation of the dimensions of Mekhala in Yagya Kund for 3 Mekhala given in YagyaMadhusoodan, 'कुण्डषड्भागिका त्वाद्या द्वितीयाअष्टांशिका स्मृता । तृतीया द्वादशांशा स्याद् इति कपिलपन्चरात्रोक्क ॥' (kundshadbhagika tvadhya dvitiya ashtashinka smruta, trutiya dvadshansha syad iti kapilpanchratrokk)" (3). It means that the dimension (outer-height and width) of the first Mekhla (last from the Kanth/ground) is $1 / 6$ of the number of hast ( 1 hast=24 angul), followed by the dimension (outer-height and width) of the second Mekhla from the ground is $1 / 8$ of the number of hast and dimension (outer-height and width) of the third Mekhla from the ground is 1/12 of the hast of the kund (3). So the dimension (outer height and width) of the bottom Mekhala of 1 hast kund would be $24 / 12=2$ angul, for middle Mekhala would be $24 / 8=3$ angul, and for upmost Mekhal would be $24 / 6=4$ angul.
These same Mekhala calculations of 'कपिलपन्चरात्रा' (Kapilpanchratra) are also represented in Kriyasaren book. It describes 'प्रधानमेखालोत्सेध्मुक्तमत्र नवांगड्गुलम् । तद्वाह्यो मेखलोत्सेधं पज्चाड्गुलमिति स्मृतं । त्वाह्यमेखलोत्सेधमड्गुलद्वितयं कमात् । चतुरिस्रद्ययड्गुलव्यासा मेखला त्रितयस्य तु ॥' (Pradhanmekhlo tsedhmuktmtra navangulam, Tdvahye mekhlotsedham panchagulamiti smratam. Tdvahy mekhlostsedhmanguldvitaym kamat, chaturistridvangul vyasa Mekhala trityasya tu) (3). It means for the Yagya Kund with three Mekhala, the inner-height of the first Mekhala that is from Kanth (from the ground) is 9 angul, followed by the inner-height of second Mekhala which is of 5 angul and the third Mekhala which is of 2 angul. The width of the same would be 4 angul, 3 angul and 2 angul respectively (Figure 3 ). In addition, the same dimensions for 3 Mekhala represented in Kriyasaren book has been mentioned by Maharshi Abhay katyayan, Mandap kund siddhi chapter 3, (8, page 81 ). The same dimensions also mentioned by Sharda Tilak Tantram book (7, page 206). 
2) Three Mekhala calculations as per Kundratnakar In addition to the Mekhala calculation by KapilPancharatra, Sharda Tilak and Kriyasaren, which recommends 4, 3, 2 angul Mekhala (outer height and width), the different opinion is by Kundratnakar, which recommends 6, 3, 2 angul Mekhala (outer height and width) has been mentioned. The Yagya-Madhusoodan has given calculation of Mekhala construction for Yagya Kund with 3 Mekhala as described in 'कुण्डरत्नारोक्त' (Kundratnakroktm) as 'क्षेत्रस्य द्वादशभागै: प्रथमायाः अष्टभागैर्द्वितियाया:, चतुर्भिर्भागै- स्तृतीयाया उत्सेधः कार्य्य इति ।' (kshetrasya dvadashbhagehah prathmayah, ashtbhagerdvetiyayah, chaturbhirbhage stritiyaya utsedhah kaaryye iti) (3). It means that the dimension (outer-height and width) of the bottom Mekhla is $1 / 12$ of the number of hast ( 1 hast $=24$ angul), followed by the dimension (outer-height and width) of the middle Mekhla from the ground is $1 / 8$ of the number of hast and dimension (outerheight and width) of the utmost Mekhla from the ground is $1 / 4$ of the hast of the kund (3, page 51). Hence, the dimension (outer height and width) of the bottom Mekhala of 1 hast kund would be 24/12= 2 angul, for middle Mekhala would be 24/8=3 angul, and for upmost Mekhala would be 24/4=6 angul.

3) Three Mekhala calculations as per Vashist Sanhita

Besides two opinions of Mekhala calculations as described above, another opinion is also given in Vashist Sanhita. It states 'प्रथमा मेखला तत्र द्वादशाड्ग्गुविस्तृता । चतुर्भिरड्गुलैस्तस्याश्चोन्नतिश्च समन्ततः ॥ तस्याश्चोपरीवप्रः स्याच्च्तुड्गुलुलुन्नतः । अष्टभिरड्गुलै: सम्यग् विस्तीर्णस्तु समन्ततः ।तस्योपरि पुनः कार्यो वप्रः सोपि तृतीयकः । चतुरड्ग्गुविस्तीर्णश्चोन्नतश्च तथा विधिः ॥' (Prathma mekhla tatra dvadashangulvistrata, chaturbhianglaestsyashchonnatishch samntatah. Tasyashchopari vaprah syachchturangulmunnatah, ashtabhirangulae samyagvistirntu samntatah.
Tasyopari punah karyo vaprah soapi tritiyakah chaturangulvistirnshchonntshch tatha vidhih) (3). It implies that for 1 hast kund the utmost Mekhala inner-height would be 12 angul from Kanth (ground), the inner-height of the second Mekhala would be 8 angul and the third would be 4 angul. The width of each of three Mekhala would be 4 angul.

This calculation of Mekhala for 1 hast given in Vashist Sanhita has been also referred to by Mandap Kund Siddhi (8, page 83), YagyaMadhusoodan (3, atha Mekhala), and Sharda Tilak book (7, Tritiya Patal, Mekhala Lakshan). As per the Chapter 3 Shloka 4 of Mandap-kund siddhi (8, page 83), 'रसांशकादुन्नतविस्तुताश्च तिस्रोअथवैका युगभागतुल्या।' (rasanshkadunntavistrutashch tistroathvaika yugbhagtulya), it implies that the dimension (height and width of the Mekhala in Yagya kund with three Mekhala would be $1 / 6$ of the hast. For example, for 1 hast (24 angul) Kund, it would be 4 angul and for other hast calculations can be made that way.

\section{For Yagya Kund with Five Mekhala}

As per the 'Yagya-Madhusoodan', 'अथ केचित् पज्चमेखला इच्छन्ति । तासां च प्रथमादिनां क्रमेण षडड्गुलः, पक्चाड्गुलश्रतुड्गुलस्स्त्र्यड्गुलो द्वयड्ग्गुलश्र विस्तारो विधीयते । तेन पज्चमेखलाविस्तारात् कण्ठतो वहिभागे विंशत्यड्गुलस्थलावगाहो भवति । अत्रोच्छ्रायः पज्चमाशेंन हसति।' (ath kechit panchmekhla ichchhanti. Tasam ch prathma dinam kramen, shdangulah, panchangulshchturngulstrayngulo dvyaangulashch vistaro vidhiyate. Ten panchMekhalavistarat kanto vahirbhage vinshtyangulsthalavgaho bhavti. ........atrochchhrayah panchmashenna hrasti) (3, page 52). It implies that for Yagya kund with five Mekhala, the width of the first Mekhala will be 6 angul, followed by 5, 4, 3 and 2 angul. This is also said by Sharada Tilak as मेखला: पज्च वा कार्या: षट्पज्चाब्धित्रिपपक्षकै:' (Mekhalah panch va karya shatpanchabdhitripakshkaeh) (7, page 208)). The 
total width (from Kath to outside) would be 20 angul. The inner-height of the first Mekhala (total inner-height of Mekhala) is 9 angul and innerheight of the second, third, fourth and fifth Mekhala can be calculated by subtracting $1 / 5$ of the total inner-height from the inner-height of previous Mekhala i.e. Inner-height of Mekhala (Y) $=[$ Innerheight of previous Mekhala] - [Total innerheight/5]. This way, the inner-height of 4th Mekhala would be 9-9/5 $=7.2$ angul (decimal is in SI system) $=7 / 1 / 5$ angul/yav/yuka. Similar calculations result in inner-height of 3rd, 2nd, and 1st Mekhala would be 5.4 angul (5/3/2 angul/yav/yuka.), 3.6 angul (3/4/6 angul/ yav/ yuka.), 1.8 angul (1/6/3 angul/ yav/yuka.), respectively $(8$, page 86$)$.

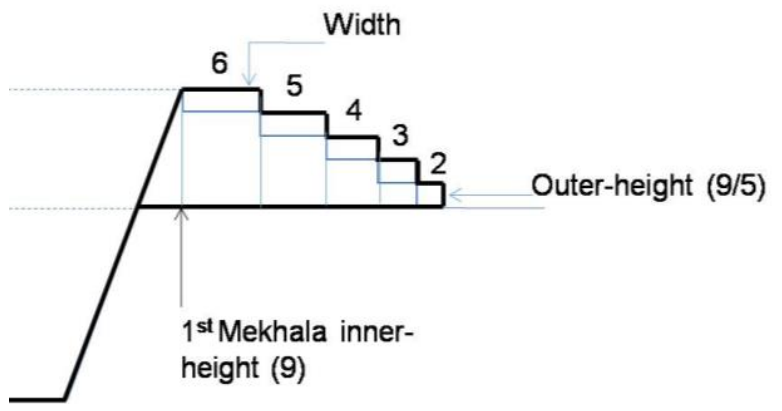

Figure 5. Dimensions of Mekhala in Yayga kund with five Mekhala. All numbers in the figure are in unit 'angul'.

The width of the bottom three Mekhala of 5 Mekhala Kund and 3 Mekhala of 3 Mekhala Kund has been the same i.e. 4,3,2 angul. For the width calculation for the three Mekhala the formula has been given in scripture (table 1), while for the five Mekhala the scripture only defined width with specific numbers i.e. 6,5,4,3,2 angul of Mekhala.

The inner-height of 1 hast Yagya kund with five Mekhala and three Mekhala has been the same i.e. 9 angul. For the five Mekhala kund, the total-innerheight (9 angul for 1 hast) is divided by five to find each of the Mekhala's outer-height i.e. 9 angul $/ 5=$ 1/6/3 angul/yav/yuka for 1 hast Yagya kund.

\section{Consideration of Number of Mekhala based on number of offerings (Yagya kund capacity) and purpose of Yagya}

The number of Mekhala vary with capacity of the Yagya Kund and number of offerings of Yagya kund (6). Scriptures describe Kunds with the number of Mekhala varying from 1 to 7 as per the purpose as well as per the capacity of the Kund and purpose of Yagya $(3,6)(7$, page 206) (8, page 80).

\section{Preference of three Mekhala and Five Mekhala}

In addition, Yagya scholars and scriptures have preferred Three Mekhala Kund over two and one Mekhala Kund and also have preferred five Mekhala kund over two and one Mekala Kund. In the Yagya-Madhusoodan book, it is mentioned as उत्तमं त्विह निर्दिष्ट्, कुण्डम् वै पज्चमेखलम् । द्विमेखलं भवेन्मध्यं हिनं स्यादेकमेखलं ॥ यद्वा मनीषिभि: प्रोक्कमुत्तम् स्यात्रिमेखलम् । द्विमेखलं भवेन्मध्यं हिनं स्यादेकमेखलं ॥ (uttam tvih nirdishtam kundam vai panch Mekhalam, dviMekhalam bhavenmadhyam hinam syadekMekhalam, yadva manishibhah prokkmuttam syatriMekhalam, dviMekhalam bhenmadhyam hinam syadekMekhalam) (3).

This is also mentioned in the Sharda Tilak, 'नाभियोनिसमायुक्तं कुण्डं श्रेष्टमं त्रिमेखलं। कुण्डं द्विमेखलं मध्यम् नीचं स्यादेकमेखलं ॥' (Nabhiyonismayuktam kundam shreshtam triMekhalam, Kundam dviMekhalam madhyam neecham syadekmekhlam). It implies that in the Yagya kund which consist of Nabhi and Yoni, 3 Mekhala are preferred over 2 Mekhala and 1 Mekhala kund (7, page 206; Nemi Lakshanam, Shloka 67-69 commentaries section). 


\begin{tabular}{|c|c|c|c|c|c|c|}
\hline \multirow{2}{*}{$\begin{array}{l}\text { Kund with Number } \\
\text { of Mekhala }\end{array}$} & \multirow{2}{*}{$\begin{array}{l}\text { Mekhala } \\
\text { construction } \\
\text { formula }\end{array}$} & \multicolumn{5}{|c|}{ Size of Mekhala in angul/yav/yuka $(\mathrm{cm})$ for 1 hast (24 angul) Kund } \\
\hline & & $\begin{array}{l}\text { Factor for calculating } \\
\text { Mekhala dimensions }\end{array}$ & Number of Mekhala & Breadth & $\begin{array}{l}\text { Outer- } \\
\text { height }\end{array}$ & $\begin{array}{l}\text { Inner- } \\
\text { height }\end{array}$ \\
\hline One Mekhala & Pingalamat & $1 / 4$ & Only one & $\begin{array}{l}6 / 0 / 0 \\
(11.4)\end{array}$ & $\begin{array}{l}6 / 0 / 0 \\
(11.4)\end{array}$ & $\begin{array}{l}6 / 0 / 0 \\
(11.4)\end{array}$ \\
\hline \multirow[t]{2}{*}{ Two Mekhala } & \multirow[t]{2}{*}{ Trantantrokte } & $1 / 6$ & Utmost (First) & $4(7.6)$ & $4(7.6)$ & $7(11.2)$ \\
\hline & & $1 / 8$ & Bottom (Second) & $3(5.7)$ & $3(5.7)$ & $3(5.7)$ \\
\hline \multirow[t]{3}{*}{ Three Mekhala } & \multirow{3}{*}{$\begin{array}{c}\text { Kapil Pancharatra, } \\
\text { Sharda Tilak and } \\
\text { Kriyasaren }\end{array}$} & $1 / 6$ & Utmost (First) & $4(7.6)$ & $4(7.6)$ & $9(17.1)$ \\
\hline & & $1 / 8$ & middle & $3(5.7)$ & $3(5.7)$ & $5(5.7)$ \\
\hline & & $1 / 12$ & Bottom (Third) & $2(3.8)$ & $2(3.8)$ & $2(3.8)$ \\
\hline \multirow[t]{5}{*}{ Five Mekhala } & \multirow[t]{5}{*}{$\begin{array}{c}\text { Yagya- } \\
\text { Madhusoodan }\end{array}$} & \multirow{5}{*}{$\begin{array}{c}\text { Inner-height of Mekhala } \\
(\mathrm{Y})=[\text { Inner-height of } \\
\text { previous Mekhala] - } \\
\text { [Total inner-height/5] } \\
\text { Total height as per } \\
\text { Three Mekhala Kund. } \\
\text { Outer-height = Total } \\
\text { height/5 } \\
\text { \#Width as given } \\
\text { scripture }\end{array}$} & Utmost (First) & $6^{\#}$ & $\begin{array}{l}1 / 6 / 3 \\
(3.42)\end{array}$ & $\begin{array}{c}9 \\
(17.1)\end{array}$ \\
\hline & & & Second & $5^{\#}$ & $\begin{array}{l}1 / 6 / 3 \\
(3.42)\end{array}$ & $\begin{array}{l}7 / 1 / 5( \\
13.68)\end{array}$ \\
\hline & & & Third & $4^{\#}$ & $\begin{array}{l}1 / 6 / 3 \\
(3.42)\end{array}$ & $\begin{array}{c}5 / 3 / 2 \\
(10.27)\end{array}$ \\
\hline & & & Fourth & $3^{\#}$ & $\begin{array}{l}1 / 6 / 3 \\
(3.42)\end{array}$ & $\begin{array}{l}3 / 4 / 6 \\
(6.82)\end{array}$ \\
\hline & & & Bottom (Fifth) & $2^{\#}$ & $\begin{array}{l}1 / 6 / 3 \\
(3.42)\end{array}$ & $\begin{array}{l}1 / 5 / 3 \\
(3.17)\end{array}$ \\
\hline
\end{tabular}

Table1. Calculations and formula for Mekhala construction of Yagya kund with one, two, three and five Mekhala. 1 angul considered is equal to $1.9 \mathrm{~cm}$.

Some scholars however, prefer 5 Mekhala over 3 Mekhala. Also as per Pinglamata given in Kundratnavali book, 5 number of Mekhala is preferred over 3 number of Mekhala; it states 'मेखलैकथावा तिस्रो भूत्संख्यथवा प्रिये॥' (mekhlaekthava tistro bhutsankhyathva priye) (15, page 13).

Regardless, preference and scriptural popularity exists for 3 Mekhala kund and 5 Mekhala kund (3, 7). Both books (Sharada Tilak Tantram and YagyaMadhusoodan) have not described Mekhala more than 5. In addition, in depth details for 3 Mekhala Kund constructions is available while for more than five Mekhala is scanty. Though LakshanSangrah opinion provides that some yagya scholars preferred 5 mMekhala over 3 Mekhala, yet applicability and available details are more available for 3 Mekhala Kund. Also 5 and 3 are both preferred over 1 and 2 Mekhala Kund, which is also well defined. Hence, the study described Mekhala calculations for 1,2,3 and 5 Mekhala Yagya kund (Table 1).

Consideration of five or higher number of Mekhala Number of offerings decides the capacity of the Kund $(13,14)$. Three Mekhala and Five Mekhala Kund are widely preferred by Yagya scholars and scripture. However, as referred in Bhavishya Puran (Khand 1, chapter 'vividh vidhi kund nirnay'), for 1 lakh ahuti (4 hast Kund), it is advised to construct 5 Mekhala Kund (shloka 26 -पंचमें खलकं वाथ लक्षकोटयां च योजयेत), while further it indicates for 8 hast and 6 hast (shloka 28 - वसुहस्ते भानुपंडिक्तार्युग्महीनेअपि ताः क्रमात्) 12 Mekhala Yagya kund shall be used. However, the book also implied that as per the capacity of performer even for the higher number of offerings, Yagya kund with 1 Mekhala shall also result in a good outcome (shloka 30) (6, page no 57). 
Number of Mekhala based on purpose of yagya

According to 'Somshambhu' mentioned in Sharada Tilak 'त्रिमेखलं द्विजे कुण्डे क्षत्रियस्य द्विमेखलं। मेखलैका तु वैश्यस्य II (TriMekhalam dvije kunde kshatriyasya dviMekhalam, Mekhalaeka tu vaeshyasya), it implies that Bramhin is advised to do yagya in yagya kund of three Mekhla, kshatriya are advised to do Yagya in yagya kund of 2 Mekhla and vaishya are advised to perform Yagya in 1 Mekhala yagya kund (7, page 206) (8, page 80). It also implies that Brahmin purpose of wisdom, Kshatriya purpose of protection, and Vaishya purpose of Business and Management can be achieved with Yagya kund with three Mekhala, two Mekhala and One Mekhala respectively. This way the number of Mekhala also depends on the purpose of the Yagya. (8 page 80 ).

\section{Mekhala significance}

Yagya represents the nucleus of all universal activities. This depiction also reflected Mekhala number and color. Three Mekhala colors are white (utmost), red (middle) and black (bottom) which reflect the three universal forces i.e. Brahma (creation), Vishnu (nurishment), Shiva (destruction-rejuvenation). In addition, three Mekhala colors, white (utmost), red (middle) and black (bottom) also reflect three Gunas (fundamental force of universe) .e. Satvik, Rajsik and Tamsik. This interpretation is given in the shloka of Sharada Tilak 'योनि लक्षण' (Yoni Lakshanam), Shloka 75 (commentaries section); it is mentioned that among these Mekhala the first Mekhala is of SATVIK phenomena, the second one is of RAJSHIK phenomena and the third one is of TAMSIC phenomena. 'सात्विकी मेखला पूर्वा विस्तृत्या द्वादशाड्गुला । द्वितीया राजसी प्रोक्ता मेखलाअष्टाड्गुलैस्ततः ।| तृतीया मेखला ख्याता तामसी चतुरड़गुला । पृथग् विस्तारमेतासुचतुरड्गुलमानतः ॥' (satviki Mekhala purva vistratya dvadashangula, dvitiya rajsi prokta Mekhalaashtaangulaesttah. Tritiya Mekhala khyata tamsi chaturangula, pruthak vistaarmetasuchturangulmantah) (7 page 212). The shloka also confirms Vashishta Samhita opinion of Mekhala dimension i.e. 4 angul (width and outer-height) of each three of Mekhala.

\section{Discussion \& Conclusion}

Mekhala holds the important aspect of the yagya kund as it not only gives Yagya kund a shape by giving a circumference to Khat but it also represents the fundamental forces of Yagya through its color and also represent physical body of Deity. The present study provided detailed construction of all types of Mekhala referenced in Yagya scripture i.e. consideration of Mekhala shape, its construction, factors for deciding numbers of Mekhala and significance of Mekhala. For Yagya kund with Mekhala 1,2, 3 and 5 all details of construction are provided in the study (Figure 1-5 and Table 1) for 1 hast. For 2 hast (), 3 hast (), 4 hast (), 5 hast (), 6 hast (), 7 hast (), 8 hast (), 9 hast (), and 10 hast (), Yagya kund Mekhala details can be simply derived from ratio calculation to the one hast. While doing this ratio calculation, the final value should be carefully converted to angul/Yav/Yuka conversion.

\section{Some considerations for Mekhala construction}

In the Kund construction, scriptures refer to the term 'विस्तार' (Vistar) of the Mekhala, which is referred to as the dimension of the Mekhala. It implied that dimensions of Mekhala include both width and outer-height of Mekhala and both are usually same (width = outer-height) unless defined. Such as in the case of five Mekhala Kund, the outer height of the Mekhala is fifth of the total height of all Mekhala. For 3, 2 and 1 Mekhala kund width is the same as outer height (except Vidhanparijat opinion).

The study had included all opinions of Mekhala given in Yagya-Madhusoodan and Sharada Tilak book except VidhanParijat opinion for 3 Mekhala 
Kund which is also not mentioned in Sharada Tilak book.

In addition, the inner-height of the Mekhala is considered from the surface (Kanth or ground). To understand it better, it can be given in the following formula as 'Inner-height of the given Mekhala = outer-height of the given Mekhala plus sum of all the lower Mekhalas' outer-height'.

\section{Consideration of total height of Mekhala for five or higher Mekhala Kund}

For 1 hast Kund with Khat, it is defined that a total 9 angul of height shall be used for Mekhala construction. Total Mekhala height for 3 Mekhala kund is 9 angul which can be calculated based on the formulas given for each of Mekhala. However, for deciding the total height for the five Mekhala kund, there is no formula given as per the books referred to by the study. Though it covered the calculation of height for all five Mekhala by subtracting one-fifth of total height (first Mekhala's inner-height) from previous Mekhala, there is no indication how to choose the total height taken 9 angul as for 1 hast kund. Hence, the study recommends a total height of three Mekhala kund for different hast kund calculation. This consideration can also be applicable for seven, twelve or other higher numbers of Mekhala.

In the five Mekhala kund, total-height (of all Mekhal) is divided into five equal parts to find each individual Mekhala's height (outer-height). This consideration can be applicable for seven, twelve or any higher number of Mekhala kund construction i.e. 7 Mekhala kund and 12 Mekhala kund by dividing the total-height into 7 and 12 parts respectively. Thus, the height calculation of Mekhala for the five or higher number of Mekhala kund is defined.
The width and height of each Mekhala for any hast of Kund can be calculated using ratio of width to the hast used for 1 hast kund. The five Mehala kund width for the 1 hast kund is found in the scripture and is defined in the study. However, the present paper could not find the width of Mekhala for the seven and twelve number of Mekhala kund having a scope of further research.

\section{References}

1. Sharma S. (pandit Shriram Sharma Acharya) and Sharma B. (Bhagwati Devi). Yajurveda Samhita. Yugnirman yojana trust. 2002. Page 3. Available from http://literature.awgp.org/book/yajurveda/v1

2. Sharma S. (pandit Shriram Sharma Acharya). Atharveda. Yugnirman Yojana Trust. 2015. Available from http://literature.awgp.org/book/atharveda/v1

3. Ojha M. 'Yagya-Madhusoodan: स्मार्तकुण्ड समीक्षा अध्याय: (SmartKund-Samiksha-Adhyayah)' chapter 'atha-khatah' (अथ खातः) and chapter atha mekhala. Vedic Press Ajmer. 1928.

4. Wisdom Library.Mekhala, Mekhalā: 31 definitions , 2021. Available from https://www.wisdomlib.org/definition/Mekhala

5. Sharma S. (Pandit Shriram Sharma Acharya). Yagya ka Gyan Vigyan (Vangmay 25). Akhand Jyoti Sansthan Mathura.1997. Section - 5.42; Available from http://literature.awgp.org/book/yagya ka gyan vigyan/v $\underline{1.1}$

6. Sharma S. (Pandit Shriram Sharma Acharya). Bhavish Puran. Sanskriti Sansthan Bareli. 1970. Pratham Khand, chapter 'vividh vidhi kund nirnay' shloka 26 -30.

7. Malviya, S. Sharda Tilak Tantram, 'तृतीय पटल' (Tritiya Patal), 'मेखला लक्षण' (Mekhala Lakshan). Chowkhamba Sanskrit Pratishthan Delhi. 2001. Vol. 1.

8. Katyayan A. Mandapkund Siddhi. Chowkhamba Surbharti Prakashan Varanasi. 2017.

9. Dikshit S. Kundratnavali. Sampurnand Sanskrit University Varanasi. 2003. (ISBN no. 81-7270-125-X).

10. Katyayan A. Kundark. Chowkhambha surbharti prakashan Varanasi. 2014.

11. Shrivardrajpranita. Laghusidhhantkoumudi, subodh sutra. Choukhambha Sanskrit bhawan, Varanasi. 2018;p582;sutra 864. (ISBN: 978-81-89986-89-6).

12. Geetapress. Bhagwat geeta. Geetapress gorakhour. 2018. verse 3.10.

13. Chandel E, Vijay V. Yagya Kunds of one-hast (24 angul) with different shapes have equal volume. Interdis. J of Yagya Res. [Internet]. 2021;3(2):01-8. https://doi.org/10.36018/ijyr.v3i2.60

14. Motlani J. The Size and Shape of Yagya Kund: Mathematical and Spiritual aspects. Interdis. J of Yagya Res. [Internet]. 2020;3(1):08-4. https://doi.org/10.36018/ijyr.v3i1.50

15. Dikshit S. Kundratnavali. Sampurnand Sanskrit University Varanasi. 2003. (ISBN no. 81-7270-125-X). Page 13 . 